\title{
Prevalence, predictors, and perceived susceptibility to placental malaria parasitemia among pregnant women in a tertiary hospital in South-Western Nigeria.
}

\author{
*Fehintola A.O. ${ }^{1}$, Fehintola F.O. ${ }^{2}$,Bakare B. ${ }^{3}$, Ayegbusi E.O. ${ }^{1}$, Ajiboye A.D. ${ }^{1}$, \\ Babalola O.E. ${ }^{1}$, Loto O.M. ${ }^{1}$
}

\begin{abstract}
Objective: Is to determine the prevalence and predictors of placental malaria among pregnant women.

Methodology: The study was cross-sectional in design. It was carried out over six months. We administered Pretested questionnaire to 300 eligible subjects. The researchers took maternal peripheral blood for malaria parasites while cord and placental blood sample at delivery for neonatal packed cell volume (PCV) and Malaria parasite. Data were analyzed using STATA 10.
\end{abstract}

Result: One hundred and forty-four (48\%) participants had placental malaria parasitemia, while 173 $(57.7 \%)$ had peripheral malaria parasitemia. Maternal age less than 20 years $(\mathrm{P}=0.008)$, low parity, and hemoglobin type AA $(\mathrm{P}=0.002)$ were significantly associated with a higher prevalence of placental parasitemia. Maternal secondary and tertiary education $(\mathrm{P}=0.013)$, perceived susceptibility to placental malaria and IPT use $(\mathrm{p}=0.014)$ were significantly associated with lower prevalence.

Conclusion: This study has shown that placental parasitemia is a significant problem in pregnancy as it is strongly associated with certain maternal factors. There is the need to intensify control efforts aimed at reducing malaria in pregnancy in Nigeria, and mothers with increased risk factors should receive more focused attention.

Keywords: Prevalence, risk factors, placental malaria, pregnancy

\author{
*Corresponding Author \\ Fehintola, A.O. \\ http://orcid.org/0000-0003-4008-1039 \\ Email: akintunds@yahoo.com
}

\footnotetext{
${ }^{1}$ Department of Obstetrics, Gynaecology, and Perinatology, Faculty of Clinical Sciences, College of Health Sciences, Obafemi Awolowo University, Ile Ife, Nigeria.

${ }^{2}$ Department of Community Health, Faculty of Clinical Sciences, College of Health Sciences, Obafemi Awolowo University, Ile Ife, Nigeria.

${ }^{3}$ Department of Obstetrics and Gynaecology, UNIMED Teaching Hospital, Ondo, Nigeria.
}

Research Journal of Health Sciences subscribed to terms and conditions of Open Access publication. Articles are distributed under the terms of Creative Commons Licence (CC BY-NC-ND 4.0). (http://creativecommons.org/licences/by-nc-nd/4.0).

http://dx.doi.org/10.4314/rejhs.v7i4.3 


\title{
Prévalence, Facteurs Prédictifs et Susceptibilité perçue à la Parasitémie du Paludisme Placentaire chez les Femmes Enceintes dans un Hôpital Tertiaire du Sud-Ouest du Nigéria.
}

\author{
*Fehintola A.O. ${ }^{1}$, Fehintola F.O. ${ }^{2}$,Bakare B. ${ }^{3}$, Ayegbusi E.O. ${ }^{1}$, Ajiboye A.D. ${ }^{1}$, \\ Babalola O.E. ${ }^{1}$, Loto O.M. ${ }^{1}$
}

\section{Résumé}

Objectif de l'étude: Déterminer la prévalence et les facteurs prédictifs du paludisme placentaire chez les femmes enceintes.

Méthode de l'étude : La conception de l'étude était transversale. Elle s'est exécutée plus que six mois. Nous avons administré un questionnaire pré-test à 300 sujets éligibles. Les chercheurs ont prélevé du sang périphérique maternel pour les parasites du paludisme, ainsi qu'un échantillon de sang de cordon et de placenta lors de l'accouchement pour le volume néonatal des accumulateurs et le parasite paludisme. Les données ont été analysées avec STATA 10.

Résultat: 144 participants (48\%) avaient une parasitémie du paludisme placentaire, tandis que 173 $(57.7 \%)$ avaient une parasitémie périphérique du paludisme. L'âge maternel moins 20 ans $(\mathrm{p}=0.008)$, la parité faible et l'hémoglobine de type AA $(\mathrm{p}=0.002)$ étaient significativement associés à une prévalence plus élevée de la parasitémie placentaire. L'éducation maternelle secondaire et tertiaire $(p=0.013)$, la perception de la susceptibilité au paludisme du placenta et l'utilisation du TPI $(p=0.014)$ étaient significativement associés à une prévalence plus faible.

Conclusion: Cette étude a montré que la parasitémie placentaire est un problème important pendant la grossesse car elle est fortement associée à certains facteurs maternels. Il est nécessaire d'intensifier les efforts de contrôle visant à réduire le paludisme pendant la grossesse au Nigéria, et les mères présentant des facteurs de risque accrus devraient recevoir une attention plus ciblée.

Mots-clés: Prévalence, facteurs de risque, paludisme placentaire, grossesse

\footnotetext{
*Auteur Correspondant

Fehintola, A.O.

http://orcid.org/0000-0003-4008-1039

Email: akintunds@yahoo.com

${ }^{1}$ Department of Obstetrics, Gynaecology, and Perinatology, Faculty of Clinical Sciences, College of Health Sciences, Obafemi Awolowo University, Ile Ife, Nigeria.

${ }^{2}$ Department of Community Health, Faculty of Clinical Sciences, College of Health Sciences, Obafemi Awolowo University, Ile Ife, Nigeria.

${ }^{3}$ Department of Obstetrics and Gynaecology, UNIMED Teaching Hospital, Ondo, Nigeria.
} 


\section{INTRODUCTION}

The female Anopheles mosquitoes transmit malaria parasites. Minute parasitic protozoa of the genus Plasmodium cause this infection. It probably originated in Africa and accompanied human migration to the Mediterranean, India, and Southeast Asia (1). Malaria causes significant morbidity and mortality in Nigeria. The disease is the most frequent cause of outpatient attendance across all age groups (2,3). An astounding 70 to 110 million clinical cases of malaria is estimated to occur per year in Nigeria. The disease accounts for $11 \%$ of maternal mortality, $25 \%$ of all infant-related death, and $30 \%$ of child-related mortality (4-7). It is also associated with maternal and childhood anemia as well as premature delivery, low birth weight babies, and fetal death.

Placental malaria is a common complication of this parasitic disease in pregnancy in areas of stable transmission. Consequently, serious health problems arise for the mother and especially her baby (8). These problems include preterm delivery, intrauterine growth restriction, low birth weight, fetal anemia, congenital malaria, and fetal mortality. In malaria-endemic countries like Nigeria, pregnant women, along with children under five years, represent the most vulnerable group to Plasmodium falciparum infection (9). Such infection often increases the risk of maternal and perinatal morbidity and mortality. Various authors have studies on placental malaria parasitemia and its effects on pregnancy and its outcomes in different parts of Nigeria (10-15). A similar survey conducted in Ile-Ife by Obiajunwa et al. in the pediatrics department of the Obafemi Awolowo University Teaching Hospitals Complex, Ile-Ife, Osun State in 2005 focused on the prevalence of congenital malaria (16). However, this study is broader and will surely go a long way to provide data for an evidence-based policy-making process in the malaria control program and better appraisal of the baseline characteristic of placental malaria.

\section{MATERIALS AND METHODS}

The study was cross-sectional in design. We conducted at the Obstetrics and Gynaecology departments of Obafemi Awolowo University Teaching Hospital Complex (OAUTHC), Ile-Ife, Osun State, Nigeria between January and July 2017. The teaching hospital comprises of four units, namely Ife Hospital Unit Ile Ife, Wesley Guild Hospital, Ilesa, Urban Comprehensive Health center, Ile-Ife, and Rural Comprehensive
Health Centre, Imesi Ile. The Ife Hospital Unit (IHU) and Wesley Guild Hospital (WGH) serve as tertiary referral centers, and the obstetric units in the two hospitals conduct an average of 2500 deliveries per year. The study populations were patients that presented for delivery at IHU and WGH. The recruitment was irrespective of the mode of delivery and booking status during the period of study. Both symptomatic and asymptomatic patients were enrolled. Researchers recruited both Mother and neonate for the survey. We excluded patients who refused to participate in the research and those who had anti-malaria treatment within the last two weeks before the onset of labor and delivery.

Consecutive sampling techniques were employed to recruits the study participants. The sample size was determined using Fisher's formula (17) with a total of 300 subjects.

The researchers used a structured intervieweradministered pre-tested questionnaire in data collection. The data obtained on basic demographics include; the age of the mother, parity, and her booking status. Other characteristics, including the educational condition of the parturient and the job description of the husband, were used for socio-economic stratification into class 1 to 5 (18). In this study, we regrouped class 1 and 2 as upper social status, class 3 as a middle social class while class 4 and 5 were grouped as the lower social status to aid data analysis. We used standardized proforma to obtain relevant obstetric data such as gestational age at the onset of labor, mode of delivery, and neonatal anthropometric measurements.

At delivery $5 \mathrm{ml}$ of peripheral venous blood was taken from the mother via venopuncture for maternal packed cell volume, ABO blood group, and blood film for the malaria parasite. Estimation of baby's packed cell volume, followed by the film for malaria parasites using the $2 \mathrm{mls}$ of cord blood collected from the portion of the cord attached to the placenta.

We obtained placental aspirate from the incision through the cotyledons on the maternal surface of the placenta. The incision was made immediately after cleaning the placenta under running water. We prepared thick and thin blood smears from the mother, umbilical cord sample, and placental aspirates. Malaria diagnosis was based on the identification of asexual forms of malaria parasites in thick films while thin films were for species identification 


\section{Data Analysis}

We carried out data entry and analysis using statistical package for social science (SPSS) version 20. Univariate analysis was carried out to determine the proportion of women with a primary and secondary outcome of interest. We carried out a bivariate analysis using $\mathrm{ch}_{\mathrm{i}}$-square and t-test.

This level of analysis determined the association between the primary outcome (presence of placenta malaria parasitemia) and selected independent variable such as educational status, age, social class, hemoglobin type, and IPT use (i.e., at least two doses) in pregnancy. For all statistical analysis, a P-value of less than 0.05 was considered significant.

Ethical Considerations: The ethics and research committee of the Obafemi Awolowo University Teaching Hospitals Complex gave clearance for the study. During data collection, the participants got adequate information about the objectives of the study, confidentiality, and the right not to participate or withdraw at any time in the study was assured. Laboratory investigations were done free of charge for the patient for this study.

\section{RESULTS}

Three hundred pregnant women were involved in the study. Of this $256(85.33 \%)$ parturient was booked while the remaining were not. One hundred and twenty-one $(40.3 \%)$ were primigravidae. One hundred and forty-one (47\%) had tertiary education, while 33 (11\%) had primary or no school. Seventy-eight $(26.0 \%)$ belong to the upper social class, while $105(35 \%)$ were of lower social status. Eleven percent had a preterm delivery, while the prevalence of low birth weight (LBW) babies was 19.7\% [Table 1]

One hundred and seventy-three (57.7\%) had positive peripheral smears with asexual forms of Plasmodium falciparum, 144(48\%) had positive placenta parasitemia while $120(40 \%)$ had positive cord parasitemia. Only $81(27 \%)$ of the respondents used ITN, while $41.7 \%$ used IPT ( at least two doses). [Table 2]

Bivariate analysis revealed that maternal age, parity, booking status, education, and hemoglobin type were significantly associated with malaria placental parasitemia. The use of IPT during pregnancy was also associated considerably with placenta parasitemia. However, the number of the dose of IPT used, the use of Insecticide-treated nets (ITN) and maternal blood group were not significantly associated with placental parasitemia. There was a significant relationship between maternal age and placental parasitemia. Age $<20$ years was associated with higher placental parasitemia rate of $88.9 \%$ compared to period $>=20$, which was $56.7 \%$ ( Fishers exact, $\mathrm{P}=0.0084$ ) as shown in Table 3. There was a significant association between lower placental parasitemia and high social class $(p=0.003)$ and higher educational status $(p<0.001)$. The unbooked parturients had a higher prevalence of placental parasitemia, and this was statistically significant $(\mathrm{P}<0.001)$. Parity was also significantly associated with the prevalence of placental malaria parasitemia $(p=0.02)$. There was a strong association between hemoglobin type and placental parasite $(p=0.002)$ with hemoglobin type AA having the highest prevalence of $45.6 \%$, while AS had a $25.6 \%$ prevalence of placental parasitemia. The use of intermittent preventive therapy (IPT) with sulphadoxine-pyrimethamine in pregnancy was strongly associated with a lower incidence of placental parasitemia $((\mathrm{p}=0.014)$ as shown in table 3 .

A logistic regression model of independent predictors for placental malaria parasitaemia showed that increasing maternal age $(\mathrm{OR}=0.55 ; \mathrm{P}=0.03, \mathrm{CI}=1.04-1.272)$, higher maternal education (secondary school and above $)(\mathrm{OR}=0.1 ; \mathrm{Z}=-2.50, \mathrm{P}=0.010, \mathrm{CI}=0.020-$ $0.625)$, the use of IPT only $(\mathrm{OR}=0.11, \mathrm{P}=0.01$, $\mathrm{CI}=0.221-0.625)$, use of both IPT and ITN $(\mathrm{OR}=0.25, \mathrm{P}=0.02, \mathrm{CI}=0.21-0.68)$, and perceived susceptibility to placental malaria were predictors of lower prevalence of placental parasitaemia while primigravidity ( $\mathrm{OR}=3.000$; $\mathrm{P}=0.001 ; \mathrm{CI}=1.530-1.900)$, and heamoglobin type $\mathrm{AA}(\mathrm{OR}=2.98, \mathrm{P}=0.015, \mathrm{CI}=1.23-7.18)$ were predictors of higher placental parasitaemia as shown in table 4.

\section{DISCUSSION}

Studies from various areas of high transmission have reported placental malaria to be a cause of varying degree of fetal growth restriction $(3,4,9)$. The prevalence of peripheral parasitemia in our study was $57.7 \%$, while that of the placental parasitemia was $48 \%$.

The peripheral parasitemia result was comparable to previous work done in other areas; Ogbodo et al (19). He found a peripheral parasitemia rate of $59.9 \%$ in the Igbo community of Ebonyi state. Obiajunwa et al (16) found a peripheral parasitemia rate of $54.2 \%$ in Ile Ife in 2005.

Placental malaria had a higher prevalence rate than values quoted from some 
other studies in the Southwest; Falade et al (20) found a prevalence rate of $13.1 \%$ in Ibadan. The exact reason for the higher prevalence of malaria parasites in this study is not known. However, we collected most of the samples for this study during the raining season. Malaria infection is at its peak during this period. This result is comparable to that from a different area in Osun State, where a rate of $63.6 \%$ malaria parasitemia was quoted (21). "The average placental parasitemia prevalence rate quoted by a multicenter study in Nigeria was $21.5 \%$ with a range between 19 and $80 \%$ depending on the method of diagnosis "(5).

In this study, the predictors of positive placental parasitemia were low parity, younger maternal age, low maternal educational status, hemoglobin type AA, and thought of not being susceptible to placental malaria. This finding is similar to that of Shuaib et al. (22). In this study, those who had secondary and tertiary education were found to have a lower prevalence of placental malaria parasitemia compared to those without formal training. The finding could be a reflection of the effect of education on awareness, and utilization of malaria control measures and their level of knowledge about malaria infestation. The impact of maternal education seen in this study contradicts the much earlier work of Okonofua et al. (6). Parental educational status has no significant effect on the prevalence of placental parasitemia, according to Okonofua et al.

The use of IPT was significantly associated with a lower prevalence of placental parasitemia in this study. Previous studies confirm this finding. The study further found that unbooked parturients had a considerably higher prevalence of placental parasitemia than booked parturient. This finding may be because booked parturient is more likely to have received and used IPT during antenatal care than the unbooked parturient. This study showed a statistically significant reduction in the prevalence of placental malaria with the use of both ITN and IPT during pregnancy. This result is in keeping with findings of Ugboaja et al. (23).

"The tools for achieving effective malaria control are now available; these include the use of ITN, IPT, effective treatment, and environmental control of vectors" (24). The production of many treatment guidelines and policy documents facilitated the use of these tools $(2,8,24)$. All stakeholders must combine efforts to ensure successful implementation in the deployment of these various tools to achieve a reduction in the burden of placental malaria (5). Worthy of note is the fact that parturients who believed that they are susceptible to placental malaria had lower parasitemia rate compared to those who did not. Perceived susceptibility to malaria parasitemia will make parturients seek protection from disease, thereby informing the use of IPT, ITN, and other malaria control measures. This finding was similar to that of a previous study on placental malaria parasitemia (23)

The limitation of this study is that we took all samples at delivery; hence, the presence or absence of placental parasite may not reflect past or chronic infection. Chronic infection usually has a profound effect on pregnancy and perinatal outcome.

Findings from this study have shown that placental parasitemia is a significant problem in pregnancy as it is significantly associated with certain maternal factors. There is the need to intensify control efforts aimed at reducing malaria in pregnancy in Nigeria, and mothers with increased risk factors should receive more focused attention.

Conflict of Interests: The authors declare that they have no competing interests. This manuscript has not been published before.

Acknowledgments: The authors acknowledge the useful contribution of Dr. Olorunfemi Ogundele of the community health department, UNIMED Teaching Hospital, Ondo, Ondo State, Nigeria, in the analysis and writing of this article.

\section{References}

1. Durojaye OA, Ilo CC, Okeowhor D, Iyaji RO, Onuorah O, James PO, Cosmas S. The Malaria Concept in Pregnancy and the Mechanism of Evading the Immune System by the Malaria Parasite. South Asian Journal of Parasitology. 2019 Jan 19:1-7.

2. Iyare FE, Uneke CJ. Effects of placental malaria on placental and neonatal birth weight of primigravidae in Southeastern Nigeria. Nigerian Journal of Experimental and Clinical Biosciences. 2018 Jul 1;6(2):59.

3. Olawale AN, Donaldson EI. On-Time Domain Analysis of Malaria Morbidity in Nigeria. American Journal of Applied Mathematics and Statistics. 2018;6(4):170-5.

4. Adeogun AO. Insecticide Resistance Associated With 2la Inversion And Microsatellite Loci Polymorphism In Anopheles gambiae Ss Populations From Lagos And the Oyo States, Nigeria (Doctoral Dissertation).

5. Mokuolu OA, Falade CO, Orogade AA, Okafor 
HU, Adedoyin OT, Oguonu TA, Dada-Adegbola HO, Oguntayo OA, Ernest SK, Hamer DH, Callahan MV. Malaria at parturition in Nigeria: current status and delivery outcome. Infectious Diseases in Obstetrics and Gynecology. 2009;2009.

6. Okonofua FE, Adeniran M, Adetugbo D, Nganwuchu A. Prevalence of malaria in women attending the antenatal clinic of Obafemi Awolowo University Teaching Hospital, Ile-Ife Nigeria. Medicare 1990;25:8-11

7. Tako EA, Zhou A, Lohoue J, Leke R, Taylor DW, Leke RF. Risk factors for placental malaria and its effect on pregnancy outcome in Yaoundé, Cameroon. Am J Trop Med Hyg. 2005;72:236-242.

8. Fried M, Duffy PE. Malaria during pregnancy. Cold Spring Harbor perspectives in medicine. 2017 Jun 1;7(6):a025551.

9. Fehintola AO, Fehintola FO, Loto OM, Fasubaa OB, Bakare B, Ogundele O. Pregnancy and fetal outcome of placental malaria parasitemia in IleIfe, Nigeria. Tropical Journal of Obstetrics and Gynaecology. 2016 Sep 1;33(3):310.

10. Dawaki S, Al-Mekhlafi HM, Ithoi I, Ibrahim J, Atroosh WM, Abdulsalam AM, Sady H, Elyana FN, Adamu AU, Yelwa SI, Ahmed A. Is Nigeria winning the battle against malaria? Prevalence, risk factors, and KAP assessment among Hausa communities in Kano State. Malaria journal. 2016 Dec;15(1):351.

11. Iyare FE, Uneke CJ. Effect of placental malaria on placental and neonatal birth weight of primigravidae in Southeastern Nigeria. Nigerian Journal of Experimental and Clinical Biosciences. 2018 Jul 1;6(2):59.

12. Izuka EO, Ugwu EO, Obi SN, Ozumba BC, Nwagha TU, Obiora-Izuka CE. Prevalence and predictors of placental malaria in human immunodeficiency virus-positive women in Nigeria. Nigerian Journal of clinical practice. 2017;20(1):31-6.

13. Oweisi PW, John CT, Omietimi JE, Aigere EO, Allagoa DO, Kotingo EL. Placental Malaria Parasitization at Delivery: Experience at a Nigerian Tertiary Hospital. European Scientific Journal, ESJ. 2018 Mar 31;14(9):243..

14. Umeobika JC, Uzoma MJ, Ojiyi EC, Ikeako LC, Ezenyeaku CT, Ezebialu IU. The Prevalence And
Correlation of Placental Malaria Parasitaemia with Neonatal Malaria and Anaemia in Orlu, South-East Nigeria. Tropical Journal of Medical and Health Science Research. 2018 Apr 18;6(1).

15. Fana SA, Bunza MD, Anka SA, Imam AU, Nataala SU. Prevalence and risk factors associated with malaria infection among pregnant women in a semi-urban community of northwestern Nigeria. Infectious diseases of poverty. 2015 Dec;4(1):24.

16. Obiajunwa PO, Owa JA, and Adeodu OO, "Prevalence of congenital malaria in Ile-Ife, Nigeria," Jof Trop ped, vol. 51, no. 4, pp. 219-222, 2005 .

17. Research methodology with statistics for health and social sciences by Margaret Olabisi Araoye. Pp 177-122, 2004 edition.

18. O. Olusanya, E. Okpere, and M. Ezimokhai, "The importance of social class in-voluntary fertility control in a developing country," West Afr J Med, vol. 4, pp. 205-211, 1985

19. Ogbodo CE, Mary JY, Barro D, Cot M. Is malarial placental infection related to a peripheral infection at any time of pregnancy? Am J Trop Med Hyg. 2005;73:1112-1118.

20. Falade CO, Mokuolu OA, Okafor HU, et al., "Epidemic of congenital malaria in Nigeria: a multi-center study," Trop Med Int Health, vol. 12, no.11,pp. 1279-1287, 2007.

21. Akinboro RA, Ojurongbe $\mathrm{O}$, Akindele AA, Adefioye OA, Bolaji OS, Olaniran O, Adeyeba OA. Plasmodium falciparum parasitemia in pregnancy in relation to maternal anemia. African Journal of Clinical and Experimental Microbiology. 2010;11(3) pp 164-169.

22. Shuaib F, Jolly P. Socio-demographic determinants of malaria in pregnancy. How well do parents in the United States report heights and weights for children?.2017 Mar 28:17.

23. Ugboaja JO, Oguejiofor CO. Efficacy of intermittent preventive treatment and insecticidetreated nets on malaria parasitemia in pregnancy among Igbo women in southeastern Nigeria. Journal of vector-borne diseases. 2017 Jul $1 ; 54(3): 249$.

24. Eastman RT, Fidock DA. Artemisinin-based combination therapies: a vital tool in efforts to eliminate malaria. Nature Reviews Microbiology. 2009 Dec;7(12):864. 
Table 1: Socio-demographics and obstetric characteristics of respondents $(\mathrm{N}=300)$

\begin{tabular}{|c|c|c|}
\hline Variables & frequency & Percentage (\%) \\
\hline \multicolumn{3}{|l|}{ Booking status: } \\
\hline Booked & 256 & 85.3 \\
\hline Un-booked & 44 & 14.7 \\
\hline \multicolumn{3}{|l|}{ Age (in years) } \\
\hline Mean $( \pm \mathrm{SD})$, Median & $29.2(5.0), 29.5$ & \\
\hline \multicolumn{3}{|l|}{ Marital status: } \\
\hline Married & 289 & 96.3 \\
\hline Single & 11 & 3.7 \\
\hline \multicolumn{3}{|l|}{ Educational status: } \\
\hline No formal & 7 & 2.3 \\
\hline Primary & 26 & 8.7 \\
\hline Secondary & 126 & 42.0 \\
\hline Tertiary & 141 & 47.0 \\
\hline \multicolumn{3}{|l|}{ Social class: } \\
\hline Upper & 78 & 26.0 \\
\hline Middle & 117 & 39.0 \\
\hline Lower & 105 & 35.0 \\
\hline \multicolumn{3}{|l|}{ Gestational age at } \\
\hline \multicolumn{3}{|l|}{ Mean $( \pm S D)$, Median } \\
\hline \multicolumn{3}{|l|}{ Parity: } \\
\hline Mean $( \pm \mathrm{SD})$ & $2.1(1.2)$ & \\
\hline \multicolumn{3}{|l|}{ Retroviral status: } \\
\hline Positive & 12 & 4.0 \\
\hline Negative & 288 & 96.0 \\
\hline \multicolumn{3}{|l|}{ Blood group: } \\
\hline A & 58 & 19.3 \\
\hline B & 42 & 14.0 \\
\hline $\mathrm{O}$ & 129 & 43.0 \\
\hline $\mathrm{AB}$ & 14 & 4.7 \\
\hline Unknown & 57 & 19.0 \\
\hline \multicolumn{3}{|l|}{ Genotype: } \\
\hline AA & 182 & 60.7 \\
\hline AS & 47 & 15.6 \\
\hline Others & 12 & 4.0 \\
\hline Unknown & 59 & 19.7 \\
\hline \multicolumn{3}{|l|}{ Mode of delivery: } \\
\hline $\mathrm{C} / \mathrm{S}$ & 121 & 40.3 \\
\hline Vaginal & 179 & 59.7 \\
\hline \multicolumn{3}{|l|}{ Delivery outcome: } \\
\hline Low birth & 59 & 19.7 \\
\hline weight $(<2.5 \mathrm{~kg})$ & 33 & 11.0 \\
\hline Preterm $(<37$ weeks $)$ & & \\
\hline
\end{tabular}


Table 2: Patterns of malarial parasitaemia and Malaria control measures used

\begin{tabular}{lll}
\hline Variables & Frequency & Percentage \\
\hline Peripheral parasitaemia: & & \\
Positive & 173 & 57.7 \\
Negative & 127 & 42.3 \\
Placental parasitaemia: & & \\
Positive & 144 & 48.0 \\
Negative & 156 & 52.0 \\
Cord parasitaemia: & & \\
Positive & 120 & 40.0 \\
Negative & 180 & 60.0 \\
IPT Use & & \\
Yes & 125 & 41.7 \\
No & 175 & 58.3 \\
Doses of IPT & & \\
1 & 93 & 42.7 \\
2 & 106 & 48.6 \\
3 & 19 & 8.7 \\
Mode of administration: & & \\
Self & 177 & 81.2 \\
DOT & 41 & 18.8 \\
Use of ITN & & \\
Yes & 81 & 27.0 \\
No & 219 & 73.0 \\
\hline
\end{tabular}

*IPT Use $=$ Proportion of patients who took at least two doses of Sulphadoxine-Pyrimethamine for prevention of malaria in the index pregnancy. 
Table 3: Association between placental malarial and selected maternal factor

\begin{tabular}{|c|c|c|c|c|}
\hline \multirow[t]{3}{*}{ Variable } & \multicolumn{3}{|c|}{ Placental parasitaemia $n=300$} & \multirow[t]{3}{*}{ Statistical remark } \\
\hline & Negative & Positive & \multirow{2}{*}{\begin{tabular}{|l|} 
Total \\
Freq. (\%)
\end{tabular}} & \\
\hline & Freq. $(\%)$ & Freq. $(\%)$ & & \\
\hline \multicolumn{5}{|l|}{ Parity } \\
\hline Primiparous & $46(38.0)$ & $75(62.0)$ & $121(100.0)$ & $X^{2}=15.5, d f=1, p=0.02$ \\
\hline Multiparous & $81(45.3)$ & $98(54.8)$ & $179(100.0)$ & \\
\hline \multicolumn{5}{|l|}{ Age group } \\
\hline$<20 \mathrm{yrs}$ & $1(11.1)$ & $8(88.9)$ & $9(100.0)$ & Fisher's exact, $\mathrm{p}=0.008$ \\
\hline$>=20 \mathrm{yrs}$ & $126(43.3)$ & $165(56.7)$ & $291(100.0)$ & \\
\hline \multicolumn{5}{|l|}{ Booking status } \\
\hline Booked & $120(46.9)$ & $136(53.1)$ & $256(100.0)$ & $X^{2}=14.7, d f=1, p<0.001$ \\
\hline Un-booked & $7(15.9)$ & $37(84.1)$ & $44(100.0)$ & \\
\hline \multicolumn{5}{|l|}{ Marital status } \\
\hline Single & $1(9.1)$ & $10(90.9)$ & $11(100.0)$ & Fisher's \\
\hline Married & $126(43.6)$ & $163(56.4)$ & $289(100.0)$ & exact, $p=0.028$ \\
\hline \multicolumn{5}{|l|}{ Educational status } \\
\hline Noformal/Pry & $8(24.2)$ & $25(75.8)$ & $33(100.0)$ & $X^{2}=15.6, d f=2, p<0.001$ \\
\hline Secondary & $43(34.1)$ & $83(65.9)$ & $126(100.0)$ & \\
\hline Tertiary & $76(53.9)$ & $65(46.1)$ & $141(100.0)$ & \\
\hline \multicolumn{5}{|l|}{ Social class } \\
\hline Upper & $41(52.6)$ & $37(47.4)$ & $78(100.0)$ & $X^{2}=11.4, d f=2, p=0.003$ \\
\hline Middle & $55(47.0)$ & $62(53.0)$ & $117(100.0)$ & \\
\hline Lower & $31(29.5)$ & $74(70.5)$ & $105(100.0)$ & \\
\hline \multicolumn{5}{|l|}{ Use of ITN } \\
\hline Yes & $40(49.4)$ & $41(50.6)$ & $81(100.0)$ & $\mathrm{X}^{2}=2.26, \mathrm{df}=1, \mathrm{p}=0.133$ \\
\hline No & $87(39.7)$ & $132(60.3)$ & $219(100.0)$ & \\
\hline \multicolumn{5}{|l|}{ Doses of IPT } \\
\hline 1 & $23(24.7)$ & $70(75.3)$ & $93(100.0)$ & $\mathrm{X}^{2}=0.37, \mathrm{df}=2, \mathrm{p}=0.829$ \\
\hline 2 & $69(65.1)$ & $37(34.9)$ & $106(100.0)$ & \\
\hline 3 & $14(73.7)$ & $05(26.3)$ & $19(100.0)$ & \\
\hline Total & $106(48.2)$ & $112(51.8)$ & $218(100.0)$ & \\
\hline \multicolumn{5}{|l|}{ Genotype $(n=241)$} \\
\hline AA & $99(54.4)$ & $83(45.6)$ & $182(100.0)$ & $X^{2}=12.57$ \\
\hline AS & $35(74.5)$ & $12(25.6)$ & $47(100.0)$ & $\mathrm{df}=2, \mathrm{p}=0.002$ \\
\hline Others & $2(16.7)$ & $10(83.3)$ & $12(100.0)$ & \\
\hline \multicolumn{5}{|l|}{$\begin{array}{l}\text { Blood group } \\
(n=243)\end{array}$} \\
\hline A & $31(53.5)$ & $27(46.6)$ & $58(100.0)$ & $X^{2}=4.44, d f=3, p=0.218$ \\
\hline B & $23(54.8)$ & $19(45.2)$ & $42(100.0)$ & \\
\hline $\mathrm{O}$ & $53(41.1)$ & $76(58.9)$ & $129(100.0)$ & \\
\hline $\mathrm{AB}$ & $5(35.7)$ & $9(64.3)$ & $14(100.0)$ & \\
\hline \multicolumn{5}{|l|}{ Use of ITN \& IPT } \\
\hline use both & $34(58.6)$ & $24(41.4)$ & $58(100.0)$ & $\mathrm{X}^{2}=11.9, \mathrm{df}=2, \mathrm{p}=0.003$ \\
\hline Use neither & $16(27.1)$ & $43(72.9)$ & $59(100.0)$ & \\
\hline
\end{tabular}


Table 4: Binary logistic regression model showing predictors of placental parasitaemia

\begin{tabular}{|c|c|c|c|c|}
\hline \multirow[t]{2}{*}{ Variable } & \multicolumn{3}{|c|}{ Positive placenta parasitaemia } & \multirow[t]{2}{*}{$95 \% \mathrm{CI}$} \\
\hline & Odds ratio & z-statistic & p-value & \\
\hline \multicolumn{5}{|l|}{ Age (years) (ref $=<20$ years) } \\
\hline$>20$ years & 0.550 & -2.920 & 0.007 & $1.048-1.270$ \\
\hline \multicolumn{5}{|l|}{ Parity (ref $=$ Multipara) } \\
\hline Primigravida & 3.000 & 1.920 & 0.001 & $1.530-1.900$ \\
\hline \multicolumn{5}{|c|}{ Educational status (ref $=$ no formal/primary) } \\
\hline Secondary & 0.233 & -1.780 & 0.004 & $.047-.150$ \\
\hline Tertiary & 0.110 & -2.500 & 0.010 & $.020-.6250$ \\
\hline \multicolumn{5}{|l|}{ Social class (ref = upper) } \\
\hline Middle & 0.420 & -1.780 & 0.000 & $.167-1.090$ \\
\hline Lower & 1.460 & 0.680 & 0.400 & $.486-4.400$ \\
\hline Gestational age at booking (weeks) & 1.020 & 0.910 & 0.360 & $.974-1.070$ \\
\hline Gestational age at delivery (weeks) & 0.950 & -0.420 & 0.670 & $.794-1.160$ \\
\hline \multicolumn{5}{|l|}{ Retroviral status (ref $=$ positive) } \\
\hline Negative & 3.200 & 1.080 & 0.270 & $.383-27.810$ \\
\hline \multicolumn{5}{|l|}{ Blood group $($ ref $=A)$} \\
\hline $\mathrm{B}$ & .6200 & -0.840 & 0.400 & $.204-1.880$ \\
\hline $\mathrm{O}$ & 1.450 & 0.910 & 0.360 & $.647-3.270$ \\
\hline $\mathrm{AB}$ & 2.280 & 0.910 & 0.360 & $.386-13.510$ \\
\hline \multicolumn{5}{|l|}{ Genotype (ref = AA) } \\
\hline AS & 3.050 & 2.500 & 0.010 & $1.273-7.340$ \\
\hline Others & 3.990 & 1.280 & 0.200 & $0.480-33.200$ \\
\hline \multicolumn{5}{|l|}{$\begin{array}{l}\text { Perceived Susceptibility to Placental } \\
\text { malaria parasitemia (ref =Yes) }\end{array}$} \\
\hline No & 2.270 & 1.730 & 0.080 & $1.898-2.770$ \\
\hline Maternal PCV & 0.840 & -.3 .640 & 0.000 & $0.772-.9200$ \\
\hline \multicolumn{5}{|l|}{ Used IPT $($ ref $=$ No $)$} \\
\hline Yes & 0.110 & -2.570 & 0.010 & $0.221-0.625$ \\
\hline \multicolumn{5}{|l|}{ Used IPT/ITN (Ref = uses both) } \\
\hline Use neither & 0.250 & -2.440 & 0.020 & $0.21-0.680$ \\
\hline
\end{tabular}

